\title{
Integrating Technology: The Principals' Role and Effect
}

\author{
Lucas J. Machado ${ }^{1} \&$ Chia-Jung Chung ${ }^{1}$ \\ ${ }^{1}$ Department of Graduate and Professional Studies in Education, California State University, Sacramento, USA \\ Correspondence: Chia-Jung Chung, Department of Graduate and Professional Studies in Education, California \\ State University, Sacramento, USA. Tel: 1-916-278-3587. E-mail: cchung@csus.edu
}

Received: December 3, 2014 Accepted: January 7, 2015 Online Published: April 27, 2015

doi:10.5539/ies.v8n5p43

URL: http://dx.doi.org/10.5539/ies.v8n5p43

\begin{abstract}
There are many factors that influence technology integration in the classroom such as teacher willingness, availability of hardware, and professional development of staff. Taking into account these elements, this paper describes research on technology integration with a focus on principals' attitudes. The role of the principal in classroom practice was found to be substantial. The purpose of this research was to assess the current attitudes concerning technology integration in schools from the school principal's perspective. This research investigated the value principals place on using technology in student learning, what principals believe prevents teachers from succeeding in technology integration, what can best facilitate teacher development, and if principals perceive peer coaching or mentoring to be a viable option. The research herein consisted of a survey and an interview to help assess principals' attitudes regarding the importance of technology integration, the perceived challenges and whether or not teacher coaches are a viable option for the future. This examination concluded that most principals in this research study value technology in education, perceive teacher willingness and professional development to be the strongest obstacles, and think teacher coaches would be a viable option for success. This study sheds light on a couple of paths for future research.
\end{abstract}

Keywords: principal, technology integration, technology coaches, common core standards, professional development

\section{Introduction}

The use of technology in United States' classrooms is rising (Project Tomorrow, 2013). Putting technology in classrooms gives teachers the tools of the $21^{\text {st }}$ century; however, the energy is only potential waiting to become kinetic upon integration. Any tool is fruitless without proper integration. Much research has been done on technology integration from the teachers' perspective, however, research is lacking from that of the school site administrator known as the principal. The skill of positive technology integration is a growing need for public school teachers. Many teachers currently do not have the technological fluency to accomplish the goals of the new national standards. These new national Common Core standards will expect teachers to facilitate students' use of technology in their learning. A wide body of studies on research-based professional development exists; however, most of this research is aimed at or concerns only teachers. It is important for administrators and teachers to work together on the common goal of preparing our youth for the future. If principals do not place a value on technology in the classroom, an integral piece of the puzzle is missing. A link between the two entities could create a deeper level of collaboration and cooperation.

To obtain a better understanding of current principals' attitudes toward technology integration, the following three research questions were developed:

- What value do principals place on the use of technology in the classroom?

- How do principals perceive the challenge of increasing teacher technology integration?

- Do principals believe technology mentors or coaches are a valid and practical solution?

This research investigated attitudes of current conditions, explored principal perspectives and data collection that can be used for future plans and goals of professional development. Research will be informational for district personnel, principals and teachers by providing a communication bridge between the entities.

\section{Review of Literature}

This review of literature examines research concerning the school principal's role and the effect on technology 
integration in the classroom. It shows that the use technology has mixed results on student achievement. It also shows there is a strong connection between teacher practice and principal influence and detailed many factors that promoted or prevented successful technology integration.

\subsection{Student Achievement}

Student achievement, the great motivator for any change to education, is examined with regard to different technologies. In order for principals to create a vision of tech savvy professionals readying students for the future, it must be worth the effort as there are many barriers and pitfalls to overcome. The result must increase student effort and motivation, complement better understanding, and prepare students for the future. One catalyst for immediate change is the new Common Core standards, which call for students to use media for presentation and research. Students will also be tested on a computer where computer literacy skills will be a definite factor.

If principals are to establish funds for technology tools, create a technology integration vision, and push for adequate professional development of teachers, they must believe that proper technology integration boosts student achievement. There is little point to any improvement in education if student achievement is not the goal. Many classrooms have made teacher-centered technology available already, however, the true goal of meaningful technology in classrooms is to move toward student-centered tools and pedagogy. Student-centered technology implies greater access for students to discover and create using innovative and engaging technology programs and devices. When technology is placed into the hands of students it becomes more interactive and therefore, student-centered. Looking at the research from teacher-centered and student-centered integration we begin to see a difference in the effectiveness. There may be other benefits for students other than higher test scores as teachers are generally in favor of using technology in increasing numbers (Project Tomorrow, 2013).

Interactive tabletops are tools with an interactive touch screen top that can be shared by a small group of students. These interactive tabletops were shown to increase mathematics achievement in elementary students when the teacher was trained adequately enough to relate the tabletop use to teaching and fix minor technical problems (Jackson, Brummel, Pollet, \& Greer, 2013). These successes were significantly impacted by the teacher's ability and willingness to learn how to apply this technology.

With greater access to tools the responsibility of all becomes greater. One to one device access is both expensive and time consuming for districts and principals. A study from Maine showed such access improved science achievement, when compared to a control group of peers who did not have 1:1 computer access (Berry, Wintle, \& University of Southern Maine, 2009). However, much of the research on 1:1 computer programs has shown mixed or modest gains in students' achievement. In some cases, this implementation has had a diminutive effect (Weston \& Bain, 2010). Another study of pilot programs found improvements in students' writing scores after being immersed in a 1:1 program (Bebell \& Kay, 2010). For example, a study of fourth grade 1:1 computer use showed improvements in writing and literacy (Suhr, Hernandez, Grimes, \& Warschauer, 2010). These mostly modest gains were coupled with resistance from some teachers, giving the study uneven results. The research suggests that most 1:1 computer programs expect the technology to automatically improve student's achievement instead of expecting teachers to integrate the computers in ways that promote cooperation, learning differentiation and problem-based learning (Weston \& Bain, 2010). The idea being that a teaching method that does not work will continue to not work with or without a computer. The mixed and varied results of 1:1 device programs might be due to mixed and varied teaching and implementation methods. In any case, these studies do not show the kind of transformative technology integration where students use a device in a meaningful way.

There is not a perfect path for administrators to invest heavily in technology tools. The more student-centered the technology, the more expensive and varied are the results. Perhaps there are more ways to evaluate the benefits of technology than there are with traditional methods. If teachers are generally becoming more interested and invested in bringing technology into the classroom, they must believe it is best for their students.

\subsection{Teacher Practice and Principal's Influence}

The role of the principal in classroom practice was found to be substantial. A schools' vision has a significant effect on that schools' organizational learning (Kurland, Peretz, \& Hertz-Lazarowitz, 2010). This was especially true when concerning technology. Various articles and studies show the important influence that school principals have on their school's environment and thusly their teachers. Common barriers to success for schools and teachers are also detailed and should be of concern to a principal.

In Chang's study of 1,000 school site staff members he concluded, "the role of the principal has also changed from solely a school administrator to the current, multi-faceted role of curricular and technological leader" (Chang, 2012, p. 337). Research also revealed that schools whose principals received technology integration 
training had higher levels of technology integration success than a control group of principals who did not receive the training (Dawson \& Rakes, 2003). The principals' attitude was found to have a specific influence on this success. While some teachers were found to be unaffected by a principal's attitude, most used more or less technology depending on the principal's support (Peled, Kali, \& Dori, 2011).

In an effort to better prepare students for the careers of the future, every school in the United States has Internet access and approximately one computer per every four students (Snyder, Dillow, \& Hoffman, 2009). Having the tools is only half of the equation. As noted earlier, the mixed results of 1:1 computer programs were thought to come from mixed results of teacher implementation. When aiming for a successful technology integration, there are barriers and obstacles on the road to implementation that must be overcome. This is because "teacher technology integration is a complex process that is influenced by both teacher characteristics and their perception of school environments" (Inan \& Lowther, 2009, p. 147). A teacher's perceptions and prejudice about technology in education affects their instructional planning. A teacher's beliefs about the effectiveness of and difficulty accompanying integrating technology may influence if they use technology in their lessons (Inan \& Lowther, 2009; Ottenbreit-Leftwich, Glazewski, Newby, \& Ertmer, 2010). In other words, teachers' attitudes toward technology, perceived computer self-efficacy and computer anxiety are important predictors of future teachers' use of computer-supported education (Celik \& Yesilyurt, 2013). The time needed to achieve the confidence and competence for bringing technology into classroom lessons is a great concern among teachers. Lack of time with regards to preparation, time spent learning the tools/devices, and time spent addressing technical failures are commonly voiced concerns (Wachira \& Keengwe, 2010). Many teachers are only interested in timesaving technology, which is often teacher-centered. Time is an essential consideration principals must remedy if they want teachers to successfully incorporate technology. The school environment is a part of the vision of the school and affects all of the teachers inside. When looking at how the school environment affects teachers' use of technology, a common element is time. Teachers appreciate the support of their school when they are given the time and resources needed to use technology (Lu \& Overbaugh, 2009). Teachers report that a supportive environment occurs when they have easy access and time to spend with the computers or devices (Zhao, Pugh, Sheldon, \& Byers, 2002).

A collection of research also outlined many barriers to successful technology integration and common success themes. A Wikipedia professional development study revealed that the lack of mentoring and a focus on pedagogy were found to be the largest barriers, while finding overall success in increasing teacher technology fluency through an extended workshop (Duran, Brunvand, Ellsworth, \& Şendağ, 2011). The term knowledge broker was identified through a synthesis of literature (Plair, 2008). This furthers the literature review's common theme of ongoing partnerships or mentoring. Through the synthesis of empirical research, the most effective professional development is one that is ongoing and learner-centered (Polly \& Hannafin, 2010).

Adequate studies exist on the practice of research-based professional development. Research also shows a strong connection between the principal's vision and school practice. If such a link between principals and classroom practice exists, research is needed to assess principal's attitudes regarding their ability to facilitate technology integration.

\subsection{A Principal's Role}

The most effective principals develop a vision and use this vision to develop a supportive learning community (Leithwood \& Riehl, 2003). It is undeniable that a schools' principal sets the vision for a school. The school environment is largely a combination of a school's vision, staff and resources. A school's environment can also be thought of as a blend of the administrations' and teachers' attitudes. These are factors which most principals have at least some control over. A schools' vision has a significant effect on that school's organizational learning (Kurland et al., 2010). There are many factors that influence what goes into this vision. The principal's own beliefs may be only a piece together with the views of the neighborhood, public and more realistically, the school district. Principals' autonomy is of no doubt varied, however, it remains true that after hire, most principals are responsible to set goals and create a vision plan for their teachers to follow. Principals who created a school vision for effective technology integration and provide teachers with on-going supportive professional development were found to be most effective. School policy certainly flows from the top down. While the tone of an individual school is a synthesis of its entire staff, the overall focus of instruction and lessons comes from the onsite administrator; the principal. Therefore, the attitudes toward and the effectiveness of technology integration in classrooms is undoubtedly affected by the principal's vision for their school.

If a schools' vision can affect teachers' teaching and a principal largely provides the vision, then the principal can affect teachers' teaching. It stands to reason, if an effective principal cares about technology integration, that 
attitude will permeate to the teachers. When it comes to technology usage, research shows that principals do have a trickledown effect of influence. Several studies confirm this logic. In a study of 1,000 Taiwanese elementary school teachers, their principals' leadership was found to have a significant effect. It was found that "principals' technological leadership improves teachers' technological literacy and directly encourages teachers to integrate technology into their teaching" (Chang, 2012, p. 328). This study also pointed to the importance of having a technology vision plan. Principals with a sound technology vision plan had the most positive influence. The study proposes the role of the principal has changed from a traditional school administrator to a curricular and technological leader (Chang, 2012). This would suggest that principals must become familiar with technology hardware as well as integration pedagogy in order to fulfill meaningful leadership roles.

Research by Dawn and Rakes indicates that schools whose principals received technology integration training had higher levels of technology integration than a control group (Dawson \& Rakes, 2003). The researchers concluded, "the more sustained the principal's training experiences and the more those experiences are tied to the school's curriculum and to the principals' needs, the more progress the school is likely to make toward technology integration" (Dawson \& Rakes, 2003, p. 45). This study shows the path of influence from the principal down to the teachers since a principals' vision is largely based on their training and experience. This study further proves a connection between principals and classroom practice.

Principals' characteristics and support have been shown to change science teachers' behaviors, whether they discourage or encourage technology use in the classroom. While some teachers were found to be unaffected by a principal's attitudes, most used more or less technology depending on principal support (Peled et al., 2011). Empowering and initiating principals may have the effect of raising the level of technology literacy and classroom usage in their teachers.

Principals set the vision and have a large effect on teaching and pedagogy in the classroom. New national standards are calling for digital media access and creation in the classroom. Therefore, principals will have a large effect on how the new funding for tech hardware is implemented in the classroom. The options for success all revolve around professional development. This means for the principal themselves as well as the teachers. Principals may want to learn the latest technology standards from reputable organizations like the International Society for Technology in Education (ISTE). They can then choose the appropriate professional development for their teachers. A recurring theme in several studies in this review was that professional development was found to be effective when it was long term or on going for the participants. Time is a challenge but also a requirement for effective development.

The use of technology coaches (mentors) may be necessary to provide this adequate in-depth long-term involvement. Both previous and current states of professional development have been described as short, infrequent workshops with little focus on ongoing support (Plair, 2008). Plair states that current technology-related professional development "lacks the continuity that teachers need to develop the confidence and efficacy leading to technology fluency" (Plair, 2008, p. 70). The article describes a knowledge broker (technology coach or mentor) as someone who "supplements the information available to teachers by attending conferences, participating in collaborative efforts with other tech-savvy teachers, and staying current with the latest literature" (Plair, 2008, p. 72). The question of whether or not principals are willing or able to pursue knowledge brokers or technology coaches in their schools is one that warrants further research.

In conclusion, more research is needed to better gauge principals' attitudes toward technology integration and provide principals with what they need to be successful. The overall influence of principals is undeniable and needs to be utilized. Due to Common Core requirements, the appearance of technology tools in the classroom and even in the hands of the students appears inevitable if not currently occurring. Many variables are contained in the equation that equals successful integration.

\section{Methodology}

As a phenomenological study of a group's attitudes, it was determined that a mixture of quantitative survey data, qualitative short answer and interview data would give a well-rounded examination. Data collection comprised of a survey featuring quantitative multiple choice and qualitative short answer questions as well as qualitative interviews with school site principals who offered their time. Results and syntheses of initial data provided further focus and possible hypotheses. The subjects were principals from four school districts in northern California. The four school districts are located in the suburb cities in two neighboring counties and all school districts offer K-12 schools. The median household income in the four school districts are either slightly below California State's median household income $(\$ 61,094)$ or much lower than California State's median household income. The student population is also equally diverse in these school districts. The school districts' 
demographics are summarized in Table 1.

Table 1. School district demographics

\begin{tabular}{llll}
\hline School Districts & $\begin{array}{l}\text { Median Household Income } \\
2009-2013 \\
\text { (USD) }\end{array}$ & $\begin{array}{l}\text { 3-Year Average Academic } \\
\text { Performance Index (API) } \\
\text { (Scores out of 1000) }\end{array}$ & Number of Schools \\
\hline School District 1 & $\$ 60,114$ & 886 & 14 \\
School District 2 & $\$ 49,753$ & 767 & 84 \\
School District 3 & $\$ 54,101$ & 779 & 67 \\
School District 4 & $\$ 29,583$ & 733 & 47 \\
\hline
\end{tabular}

Sources: U.S. Census Bureau \& California Department of Education.

Two waves of emails were sent to every active principal listed on each of the school district's website. These included elementary, middle and high school level. It also included charter schools that are associated with one of the four school districts. A total of 200 principals were successfully emailed with a personalized greeting to persuade participation. 42 principals participated in the survey showing a return rate of $21 \%$. Variables in this study can be divided into two groups; demographics and opinions. Demographics consist of constants like gender, age, and school level and technology infrastructure at the school site. These variables were compared to opinions to find patterns or trends. During data analysis, constants were controlled for in order to find relationships to opinions. For example, age group was divided and results observed to find out if age had a correlation to an opinion. Quantitative survey data provided tables of answered questions in order to find consensus or discrepancies in opinions. This data is compared with known research concerning similar surveys of school personnel. In addition, qualitative interviews add more depth and personal account of the administrator's perspective. Qualitative analysis was compared to survey data, interviews and current research.

\section{Results}

The data presented herein will be broken down by each survey question. First, the demographic data will be presented. Then, the quantitative data concerning principles' opinions will be presented. All percentages were rounded to the nearest whole number. Next, the researchers will analyze qualitative short answer questions. Finally, the interview questions will be summarized.

\subsection{Demographic Data}

According to the demographic data collection with a survey of gender and age, $48 \%$ were male and $52 \%$ were female giving a nearly even split. $33 \%$ were ages $35-44,38 \%$ were ages $45-54$ and $29 \%$ were 55 to 64 . No participants were under 35 or over 64 years of age. This also shows a near even split among participating age groups.

The next two demographic questions concerned the school setting. The data shows $57 \%$ were in elementary school, $7 \%$ were in K-8, 17\% were in middle school, and 19\% were in high school. The last demographic survey question concerned technology hardware and infrastructure. The question asked was, "What kinds of technologies are available at your school?" Responses can be seen in Table 2. Since $88 \%$ of the participating school sites offer Wi-Fi Internet, a computer lab and document cameras in the classrooms, it can be assumed that most of the participants' schools have these technologies. 
Table 2. Kinds of technologies available at school

\begin{tabular}{ll}
\hline Answer Options & Response Percent \\
\hline Computer Lab & $88.1 \%$ \\
Wi-Fi Internet & $97.6 \%$ \\
Document Cameras (in most classrooms) & $88.1 \%$ \\
SMART boards (in most classrooms) & $52.4 \%$ \\
Tablet Cart & $33.3 \%$ \\
Laptop Cart & $57.1 \%$ \\
1 to 1 Tablets (in at least one classroom) & $11.9 \%$ \\
1 to 1 Computers (in at least one classroom) & $31.0 \%$ \\
\hline
\end{tabular}

\subsection{Principals' Opinion Data}

The first question began the assessment of principals' attitudes toward technology integration by asking, "How important is it that your teachers integrate technology into their teaching?" $98 \%$ of principals value integration as either important or highly important. $0 \%$ answered unimportant or below. This speaks highly to the researchers' question on the value placed on integration by principals. It is however, one thing to click a box on a survey and another to expend the time and energy of action. A more effective gauge of principals' true opinion might be to look at the action taken in the form of professional development. Another question stated, "Identify what percentage of teachers at your school is effectively using technology in the classroom?" According to the results, only $38 \%$ of principals thought $75 \%$ or more of their teachers were integrating technology effectively.

Regarding the question "Rank the following in order of importance with regard to teacher technology integration", the three options were: willingness of teacher, professional development, and support from the principal. Notably, most principals ranked the willingness of teachers of the highest importance (61\%). Also, most principals ranked their own support as the least important (56\%). This may suggest an undervaluing of the principal's own influence. It also identifies the unwillingness of teachers as a potential challenge for principals. Responses can be seen in Table 3.

Table 3. Rank of importance with regard to teacher technology integration

\begin{tabular}{lcccc}
\hline Answer Options & $1^{\text {st }}$ & $2^{\text {nd }}$ & $3^{\text {rd }}$ & Ranking Average \\
\hline Professional Development & 8 & 18 & 15 & 2.17 \\
Willingness of Teacher & 25 & 13 & 3 & 1.46 \\
Support from Principal & 8 & 10 & 23 & 2.37 \\
\hline
\end{tabular}

The principals were also asked to "Identify the top three roadblocks preventing teachers from integrating technology in their classrooms." Table 4 shows the top answers by rank of most important and by overall mentions. Teacher willingness again was perceived to be a top challenge by the principals; however professional development was mentioned the most. The last question was "What do your teachers need to ease the transition into technology integration?" 98\% of respondents' answers included time for professional development and planning. A few responded that money and resources were also needed. Only one respondent stated that his/her staff was "well versed in technology." Since principals listed teacher willingness as their top challenge and time for professional development as their teacher's greatest need, these results suggest principals think that more professional development time will change the attitudes of the teachers. 
Table 4. Top three roadblocks preventing teachers from integrating technology

\begin{tabular}{llll}
\hline & 1 & 2 & 3 \\
\hline By Rank Importance & Teacher Willingness & Professional Development & Lack of Infrastructure \\
By Overall Mentions & Professional Development & Teacher Willingness & Lack of Infrastructure \\
\hline
\end{tabular}

There were two survey questions related to peer coaching for teacher development. One question asked, "Do you think technology peer coaching/mentoring is a valuable option for professional development in this area?" $95 \%$ of participants felt that teacher coaches are a valuable option. It would have been advantageous to know why $5 \%$ did not think it is a good idea. The other question asked, "Is it viable to pay peer coaches/mentors?" The majority $(59 \%)$ answered no, meaning it is not viable to pay these teacher coaches. Principals here think teacher coaches are a good idea, but most say they cannot pay them. This means teacher coaches would need to be willing to work extra hours for free. Since many principals in this study are interested in the idea of teacher coaches, an interesting area of study might be the effectiveness of teacher coaching programs.

To provide more qualitative data, the final open-ended question asked, "Could a peer coaching system work at your school?" 4 principals indicated they already have a similar system in place. $95 \%$ of respondents were open to the idea and left various conditions for success. The most common conditions were additional funding and time. Since most school sites (74\%) had a technology-savvy teacher on site, a common answer suggestion was that district funds could pay teachers to put in extra work time to learn from each other.

\subsection{Principal Interviews}

The researchers conducted 4 interviews over the course of the data collection period. Interviews were conducted over email to give participants time to reflect, respond at their convenience and for strict consistency of interview questions. Interviewees' responses are summarized here for brevity and to preserve anonymity.

Results of this interview indicated that technology integration is "critical" for students if "used correctly." Thus, a high value was placed on it. Principles also felt the new Common Core testing will require better "keyboarding and navigation" skills for their students. These same findings were also reflected in the initial survey.

When asked, "What does your district currently do to raise technology fluency?" All respondents said it is up to the teachers to seek out professional development opportunities. One principal wrote, "I think there are online classes available to teachers." Another wrote, "There is nothing district-wide. It is up to the individual teacher and/or administrator." Confirming, another principal wrote, "Each school site is responsible for teacher training for technology." No respondents wrote about mandated or required district trainings.

In another question, principles were asked, "What do you think prevents some teachers from integrating technology?" In this question, a consensus was reached as three of four included the word "fear" referring to their teachers in their response. One wrote, "Mostly fear of the unknown or that they (teachers) will somehow "hurt" the system or the computer." Another wrote, "Some teachers are fearful and have never been taught." Other concerns were "lack of actual technology" and "lack of training." It appears that after technology hardware is at the school site, principles' concerns reside in the lack of training and teacher willingness, which may be a symptom of fearfulness.

In an attempt to ascertain if principals had a school vision plan for technology the following question was asked; "Are there any future goals for assisting teachers integrating technology into their classrooms?" None of the respondents indicated having a clear technology plan. The closest was, "we are starting a once a month class for teachers on campus." Another wrote, "We have purchased iPads and now have MacBook carts and we are going to come up with a school site technology plan." A telling response was, "we have the new Macs (laptops) for the SBAC (common core testing,) but not a clear plan on how to use them." According to the findings in recent literature, "schools must develop a long-term technology plan with a vision and goals for the school's faculty and staff" (Chang, 2012, p. 336). According to one principal, "it is such a balancing act with all the needs to be learned in order to continue with $21^{\text {st }}$ century learning."

Finally, to add qualitative data to the research question concerning teacher coaches/mentors one interview question stated, "Do you think technology coaches/mentors could be a viable option for school districts?" In agreement with the survey results, principals here were responsive to the idea of technology coaches. "Teachers will need support on a regular basis as well as ongoing professional development," wrote one respondent. Also, in accordance with the survey, money was a qualification. "Coaches would be ideal if the budget allowed," wrote one principle. A few insights as to how this process might work were also given. One principal responded, "It 
would be great if there were coaches that sites could use to teach classes on our site after school." Another mentioned, "I think it would be particularly helpful if the ELA/Math coaches we currently have could have training in technology as well."

In short, these interviewees aligned with the survey consensus in their opinions; however, they also offered some interesting insights. One such insight was that school sites might not feel a technology plan is needed until one-to-one devices are purchased. Two principles indicated the need for a plan now that they have laptops, iPads or and MacBook carts. However, why didn't these principals feel a technology plan was needed when they were able to provide WiFi access, document cameras, and one computer lab? Perhaps they felt that the basic technology was not enough to make a great pedagogical change.

Another insight is that teachers' unwillingness may be due to fear of the unknown, the antidote for which is building comfort levels with trainings/time with technology. The only solution to overcoming teachers' fears is with on-going professional support. If one is trying to find solutions to better integrate technology with fearful teachers, all roads lead to professional development.

Finally, after conducting interviews it became clear principals do not think they can be successful in this endeavor without adequate hardware or support. As one principal put it, "Unless teachers get the technology and the training, it will be a source of resentment for the teachers that are expected to use 'it'."

\section{Findings}

In this section, the researchers took data results and applied them to each of the three research questions. For each question a finding was issued and is discussed herein. In short, principals highly value technology in education. They believe teacher's preconceptions and district support to hinder progress. Finally, they think teacher coaches could provide the needed training; however, they currently cannot be paid under existing conditions.

\subsection{Finding 1: What Value Do Principals Place on the Use of Technology in the Classroom?}

In answer to the first research question, most principals in this study report they highly value technology use in their classrooms, yet most do not provide adequate training or have their teachers currently integrating. This possible answer to this research question was derived from a potential discrepancy. The inconsistency was found when most principals (98\%) signified that technology was important, yet did not have at least $75 \%$ of their teachers integrating technology (38\%) or have adequate professional development $(40 \%)$. The old saying, "actions speak louder than words" would have us believe that principals do not really value technology. However, we can only hold principals accountable for what they have control of. Principals indicated several challenges including teacher willingness, professional development, insufficient hardware and district support. Teacher willingness, which may be based on fear of the unknown, might be blocking principals; however, more professional development would rectify this potential source of apprehension. Also, how much control do principals actually have over their sites' funding for professional development? It is possible that most principals truly value integration of technology, but do not have the money to back that belief up with action. The level of a principal's autonomy over school site funds varies from district to district. Given the benefit of the doubt, principals do value proper technology integration in education, but need more control over their funds or more funds to spend on what they value as important.

Another explanation for this discrepancy may be time. In fact, all postulating is mute if there is simply not enough time in teachers' current schedules for a new area of expertise. The curriculum requirements seem to be growing every year. In the fall of 2014, a completely new set of standards and pedagogy were commenced in California (Common Core). This new system includes budgets for technology hardware in schools. How will teachers learn to use it if their current schedules, contracts or pay does not allow for any more time? An interesting subject for further study might be to look into these teachers' time outside of actual classroom teaching. Is it feasible for them to incorporate a new subject of trainings into their time outside of class?

Upon reflection, the researchers felt an important question for principals would have been, "Why is or isn't technology integration important in education?" The answers might have added validity to their high opinion of technology integration. If valid reasons were ascertained, one could be surer of the high value being placed on technology integration, as it is not just checking the box that "makes me look good" or "agrees with current trends."

\subsection{Finding 2: How Do Principals Perceive the Challenge of Increasing Teacher Technology Integration?}

In this study, most principals perceive the top challenges of technology integration to be teacher willingness, professional development and district support. They believe their role to be of lesser importance. Principals' 
opinions in this area concurred with previous research findings. A teacher's beliefs about the effectiveness of and difficulty accompanying integrating technology were found to influence whether or not they use technology in their lessons (Inan \& Lowther, 2009; Ottenbreit-Leftwich et al., 2010). In other words, teachers' attitudes toward technology, perceived computer self-efficacy and computer anxiety are important predictors of teacher's use of computer-supported education in the future (Celik \& Yesilyurt, 2013). When principals ranked teacher willingness as a great factor, they were concurring with previous findings.

Professional development was also found to be of importance in previous findings (Duran et al., 2011). As mentioned earlier in this paper, the only cure for teacher willingness is professional development either with an expert or simply time for the teachers to get comfortable using technologies. So, listing teacher willingness as a hurdle is the same as listing professional development as a hurdle since one would alleviate the other. Accepting this premise means that principals overwhelmingly think teachers need more time and guidance with the tools than they are currently receiving.

According to the research outlined in the survey of literature in this paper, principals have a great role in the classroom functioning. Principals in this study ranked their importance in the symphony needed to successfully integrate technology below teacher willingness and professional development. However, this does not mean principals think their role has no influence. In reflection, ranking did not show the desired result intended by the researchers. A more effective way to distinguish if principals realize the power that their position holds would have been to ask, "How much influence do you (principals) have over classroom practice, specifically technology use in the classroom?"

\subsection{Finding 3: Do Principals Believe Technology Mentors or Coaches Are a Valid and Practical Solution?}

In response to the third research question, most principals think technology coaches would provide needed training, however, compensation from the school site may not be realistic. If teacher willingness is only rectified by time spent with technology and professional support, then coaches who provide ongoing support would change the teachers' attitudes. Research shows positive links to time and support. Teachers appreciate the support of their school when they are given both the time and resources to use technology (Lu \& Overbaugh, 2009). Teachers report a supportive environment occurs when they have easy access to and time with the computers or devices (Zhao et al., 2002). In theory, coaches would be available for trouble shooting problems while teachers become familiar with the devices.

According to Plair's study conducted in 2008, previous and even current states of professional development are mostly short, infrequent workshops with little focus on ongoing support (Plair, 2008). This author goes on to state that current technology-related professional development "lacks the continuity that teachers need to develop the confidence and efficacy leading to technology fluency" (Plair, 2008, p. 70). Providing teachers with the kind of support needed to develop confidence and efficacy means that the principals need to have a designated person or persons who are both knowledgeable and frequently available to them. Perhaps a grant could support a teacher coaching experiment or a study might be done to examine the schools whose principals responded that they already have a teacher coaching system in place. The researchers believe that since technology is ever and rapidly changing, most teachers will not be able to keep up with the latest tools without help from a teacher coach acting as a knowledge broker. This, like most positions, would be more effective if the teacher coach is compensated for their service.

\section{Conclusions}

This study sheds light on a couple paths for future research. Since most principals were open to the idea of teacher coaches and already have the personnel to conduct a teacher coaching program, more research could be done to evaluate the effectiveness and viability of such a program. Another path might be to research whether or not principals realize that current research says they must have a technology vision plan in order to promote technology integration in their schools. This paper suggests they might not realize their own strength and influence in this subject. Lastly, many studies have been conducted in this area with a focus on the teacher and student. More research is needed on the role of and the effect the principal has on technology integration since they are responsible for organizing and enforcing the school vision and plan.

\section{References}

Bebell, D., \& Kay, R. (2010). One to one computing: A summary of the quantitative results from the Berkshire wireless learning initiative. Journal of Technology, Learning, and Assessment, 9(2). Retrieved from http://www.jtla.org

Berry, A. M., Wintle, S. E., \& University of Southern Maine. (2009). Using laptops to facilitate middle school 
science learning: The results of hard fun. Center for Education Policy. Applied Research, And Evaluation. Retrieved from http://files.eric.ed.gov/fulltext/ED509453.pdf

California Department of Education. (2013). Academic Performance Index (API). Retrieved from http://star.cde.ca.gov/star2008/Viewreport.asp

Celik, V., \& Yesilyurt, E. (2013). Attitudes to technology, perceived computer self-efficacy and computer anxiety as predictors of computer supported education. Computers \& Education, 60(1), 148-158. http://dx.doi.org/10.1016/j.compedu.2012.06.008

Chang, I. H. (2012). The effect of principals' technological leadership on teachers' technological literacy and teaching effectiveness in Taiwanese elementary schools. Educational Technology \& Society, 15(2), 328-340.

Dawson, C., \& Rakes, G. C. (2003). The Influence of Principals' Technology Training on the Integration of Technology into Schools. Journal of Research on Technology in Education, 36(1), 29-49. http://dx.doi.org/10.1080/15391523.2003.10782401

Duran, M., Brunvand, S., Ellsworth, J., \& Şendağ, S. (2011). Impact of Research-Based Professional Development. Journal of Research on Technology in Education, 44(4), 313-334. http://dx.doi.org/10.1080/15391523.2012.10782593

Inan, F. A., \& Lowther, D. L. (2009). Factors affecting technology integration in K-12 classrooms: A path model. Educational Technology Research and Development, 58(2), 137-154. http://dx.doi.org/10.1007/s11423-009-9132-y

Jackson, A. T., Brummel, B. J., Pollet, C. L., \& Greer, D. D. (2013). An evaluation of interactive tabletops in elementary mathematics education. Educational Technology Research and Development, 61(2), 311-332. http://dx.doi.org/10.1007/s11423-013-9287-4

Kurland, H., Peretz, H., \& Hertz-Lazarowitz, R. (2010). Leadership style and organizational learning: The mediate effect of school vision. Journal of Educational Administration, 48(1), 7-30. http://dx.doi.org/10.1108/09578231011015395

Leithwood, K. A., \& Riehl, C. (2003). What we know about successful school leadership. Philadelphia, PA: Laboratory for Student Success, Temple University.

Lu, R., \& Overbaugh, R. C. (2009). School Environment and Technology Implementation in K-12 Classrooms. Computers in the Schools, 26(2), 89-106. http://dx.doi.org/10.1080/07380560902906096

Ottenbreit-Leftwich, A. T., Glazewski, K. D., Newby, T. J., \& Ertmer, P. A. (2010). Teacher value beliefs associated with using technology: Addressing professional and student needs. Computers \& Education, 55(3), 1321-1335. http://dx.doi.org/10.1016/j.compedu.2010.06.002

Peled, Y., Kali, Y., \& Dori, Y. (2011). School principals' influence on science teachers' technology implementation: A retrospective analysis. International Journal of Leadership in Education, 14(2), 229-245. http://dx.doi.org/10.1080/13603124.2010.524249

Plair, S. K. (2008). Revamping Professional Development for Technology Integration and Fluency. The Clearing House, 82(2), 70-74. http://dx.doi.org/10.3200/tchs.82.2.70-74

Polly, D., \& Hannafin, M. J. (2010). Reexamining technology's role in learner-centered professional development. Educational Technology Research and Development, 58(5), 557-571. http://dx.doi.org/10.1007/s11423-009-9146-5

Project Tomorrow. (2013). Speak Up: From Chalkboards to Tablets: The Digital Conversion of the K-12 Classroom. Retrieved from http://www.tomorrow.org/speakup/SU12_EducatorsandParentsTEXT.html

Snyder, T. D., Dillow, S. A., \& Hoffman, C. M. (2009). Digest of Education Statistics 2008 (NCES 2009-020). National Center for Education Statistics, Institute of Education Sciences, U.S. Department of Education. Washington, DC.

Suhr, K. A., Hernandez, D. A., Grimes, D., \& Warschauer, M. (2010). Laptops and fourth-grade literacy: Assisting the jump over the fourth-grade slump. Journal of Technology, Learning, and Assessment, 9(5). Retrieved from http://www.jtla.org

U.S. Census Bureau. (2014). State and County Quick Facts Washington, D.C.: Government Printing Office. Retrieved from http://quickfacts.census.gov/qfd/states/\#

Wachira, P., \& Keengwe, J. (2010). Technology Integration Barriers: Urban School Mathematics Teachers 
Perspectives. J. Sci. Educ. Technol., 20(1), 17-25. http://dx.doi.org/10.1007/s10956-010-9230-y

Weston, M. E., \& Bain, A. (2010). The end of techno-critique: The naked truth about 1:1 laptop initiatives and educational change. Journal of Technology, Learning, and Assessment, 9(6). Retrieved from http://www.jtla.org

Zhao, Y., Pugh, K., Sheldon, S., \& Byers, J. L. (2002). Conditions for Classroom Technology Innovations. Teachers College Rec, 104(3), 482-515. http://dx.doi.org/10.1111/1467-9620.00170

\section{Copyrights}

Copyright for this article is retained by the author(s), with first publication rights granted to the journal.

This is an open-access article distributed under the terms and conditions of the Creative Commons Attribution license (http://creativecommons.org/licenses/by/3.0/). 